\title{
International Consumer Demand for Organic Foods
}

Gary Thompson

\begin{abstract}
Summary. Sales of organic foods at retail have grown at rates from 20 to $35 \%$ in many countries throughout E urope, A sia, and the Americas during the 1990s. Yet market shares of organic foods remain quite small, less than $3 \%$ of retail value in all countries throughout the world. As mainstream retail outlets have begun to carry and promote organic foods, lack of availability of organic foods has become less of an impediment to consumer demand. The major impediment to continued growth in organic food demand is high price premiums for organic foods over conventional food counterparts. Some of the highest price premiums at retail are displayed by fresh and frozen vegetables and fruit: premiums as high as $250 \%$ for frozen green peas (Pisum sativum L.) in the U nited States have been recorded. Indirect evidence in the form of willingness-to-pay studies and retail pricing experiments indicate that the majority of consumers will not pay such high price premiums for organic fruit and vegetables. Small market shares at retail tend to corroborate consumers' unwillingness to pay such high prices. H ow much prices of organic fruit and vegetables would have to be reduced relative to conventional produce in order to increase market shares of organic produce is not clear.
\end{abstract}

$\mathrm{T}$

he decade of the 1990s has witnessed the emergence of organic food products from specialty outlets into mainstream retail venues in many countries throughout the world. Yet paradoxically, wider availability of organic foods has not yet boosted retail sales beyond niche market status. Even in the countries with the largest retail markets for organic foods, the share of organic food sales does not exceed $3 \%$ of total retail food sales (Table 1 ). What are the prospects for future growth in organic food sales throughout the world? Why has high growth in sales of organic foods not translated into larger market shares of retail food value? This paper will attempt to answer these questions by first describing the development of organic food markets in major consuming countries and then analyzing consumer traits and behavior as well as market developments which may lead to growth in organic food consumption. 


\section{Organic food consumption around the world}

All countries with relatively large consumption of organic foods possess high levels of per capita income (T able $1)$. The sole exception is China where "green" food-notstrictlyorganicfoods by most other countries' definitionshas become more popular in some urban areas (Wang et al., 1997). The U nited Statesconstitutesthesinglelargest market for organicfoodsfollowed by G ermany and J apan. Various other E uropean countries are the next largest organic markets. The smallest markets for organic foods appear to be Canada, Australia, and Belgium. The markets in which the highest shares of retail sales are organic foodstend to besmall countries such as Denmark, Austria, and Switzerland. Per capita expenditures on organic foods are moderately positively correlated $(r=0.63)$ with per capita income levels but a major exception is Japan. In broad terms, organic foods tend to beluxury items in the sensethat their consumption is highest in coun- tries with high per capita incomes.

Piecemeal information about organic food markets in some middle income countries suggests that retail markets are still in early stages of development. In Argentina, about 50 different organic products are available in major supermarkets ( $M$ alz, 1998). Imported organic foods and beverages as well as domestically produced organic fruit, vegetables, rice, and tea are sold primarily in specialty stores in Taiwan (Perng, 1998). O rganic foods are available on a limited basis in $\mathrm{H}$ ong $\mathrm{K}$ ong (Thorburn, 1998). I n C hile, themarket for organic foods isjust beginning to be evident: only a single store in Santiago stocked locally produced organic foods like vegetables, eggs, and cheese (Zygmont, 1998). Some middle income countries will likely have larger shares of organic products in the future but current sales appear to bevery modest in absolute terms.

\section{Importance of organic hortic ultural products}

The incipient nature of many mainstream markets for organic foods means that comparable data on consumption of organic productsin many countries are nonexistent. N onetheless, spotty data on the composition of organic food items consumed in a few countries do exist (T able 2). H orticultural products- principally fruit and vegetables-areamong themost prevalent products in the mix of organic foods sold at retail; fruit and vegetables account for more than twothirds of retail organic sales in both the $U$ nited Kingdom and Australia and about half of sales in Austria. Lessthan half of organic sales are accounted for by fruit and vegetables in France while in Germany they account for just a quarter of retail sales. In all of the countries mentioned, fruit and vegetables together account for the single largest category of organic sales, larger than sales of dairy products, meat, cereals or other categories.

Reliable data for estimating the share of organichorticultural products in the U nited States are not available. Thereareseveral fundamental difficul-

T able 1. Size and share of organic markets throughout the world.

\begin{tabular}{|c|c|c|c|c|c|}
\hline Country & $\begin{array}{c}\text { Market } \\
1997 \\
\text { size } \\
1997 \\
\text { (million \$) } \\
\end{array}$ & $\begin{array}{c}\text { Market } \\
\text { share } \\
\text { (\% of total food sales) }\end{array}$ & $\begin{array}{c}\text { Population } \\
(\$)^{s}\end{array}$ & $\begin{array}{c}\text { G ross national } \\
\text { product/capita } \\
1995 \\
(\$)^{5} \\
\end{array}$ & $\begin{array}{c}\text { Per capita } \\
\text { expenditure on } \\
\text { organic food } \\
1995 \\
\end{array}$ \\
\hline \multicolumn{6}{|l|}{ Europe $^{z}$} \\
\hline Germany & 1,800 & 1.2 & 82 & 27,510 & 22.0 \\
\hline I taly & 750 & 0.6 & 58 & 19,020 & 13.0 \\
\hline France & 720 & 0.5 & 56 & 24,990 & 12.9 \\
\hline U nited Kingdom & 450 & 0.4 & 59 & 18,700 & 7.6 \\
\hline $\mathrm{N}$ etherlands & 350 & 1.0 & 16 & 24,000 & 22.3 \\
\hline Switzerland & 350 & 2 & 7 & 40,630 & 48.6 \\
\hline D enmark & 300 & 2.5 & 5 & 29,890 & 60.0 \\
\hline Austria & 225 & 2 & 8 & 26,890 & 28.1 \\
\hline Sweden & 110 & 0.6 & 9 & 23,750 & 12.5 \\
\hline Other & 200 & & 83 & 15,226 & 2.4 \\
\hline Total & 5,255 & & 382 & & 13.7 \\
\hline \multicolumn{6}{|l|}{ N orth America } \\
\hline U nited Statesy & 4,000 & $1-1.6$ & 266 & 26,980 & 15.0 \\
\hline Canada ${ }^{x}$ & 68 & 1 & 30 & 19,380 & 2.3 \\
\hline \multicolumn{6}{|l|}{ Asia } \\
\hline Japan w & 1,700 & 1 & 125 & 39,640 & 13.6 \\
\hline Chinav & 1,200 & 6 & & 620 & \\
\hline Australia" & 60 & 0.2 & 18 & 18,720 & 3.4 \\
\hline N ew Z ealand ${ }^{t}$ & 22 & $?$ & 4 & 14,240 & 6.1 \\
\hline
\end{tabular}

zInternational Trade Centre, 1999. O ther Europe includes Belgium, Finland, Greece, I reland, Portugal, Spain, and N orway.

yN atural Foods M erchandiser, 1998.

xM yles, 1997.

wSeki, 1997.

vWang et al., 1997.

uH udson, 1996.

tSaunders et al., 1997

sWorld Bank, 1996 
T able 2. H orticultural products as a percentage of organic food sales.

\begin{tabular}{lccc}
\hline Country & $\begin{array}{c}\text { Fruit } \\
(\%)\end{array}$ & $\begin{array}{c}\text { Vegetables } \\
\text { (\%) }\end{array}$ & $\begin{array}{c}\text { Total } \\
\text { (\%) }\end{array}$ \\
\hline Australia $^{z}$ & 34 & 35 & 69 \\
U nited Kingdom $^{y}$ & 21 & 47 & 68 \\
Austria $^{\mathrm{x}}$ & 30 & 20 & 50 \\
France $^{\mathrm{w}}$ & --- & --- & 40 \\
Germany $^{\mathrm{v}}$ & 12 & 13 & 25 \\
\hline
\end{tabular}

zH udson, 1996.

×L atacz-L ohmann and Foster, 1997.

YKrucsay, 1996.

wG authier, 1996.

ties in obtaining such figures. First, an unknown but presumably significant portion of retail sales of organic fruit and vegetables still take place outside of mainstream retail chains in farmers markets, local cooperatives, roadside stands, and direct deliveries. Seasonal and geographic variation in the availability of fresh organic produce aswells as varying rates of shrink or loss in the distribution chain make it impossible to estimate reliably the magnitude and composition of these sales. Second, even sales of organic fruit and vegetables in retail chains are often difficult to track because many bulk items have no bar codes and can not be scanned. Even though price lookup ( $P L U)$ codes have been widely adopted, most scanner data services have not collected them because human errors in entering PLU codes by hand lead to poorer quality data than if such items could be scanned. While PLU s for organic products do exist, PLU tracking systems differ across retail chainsmaking aggregation of $P L U S$ tedious and costly. A further complication is that random-weight items such as iceberg lettuce ( Lactuca sativa
L.) aresold by thehead so that no price per unit of weight can be retrieved (E astwood, 1997). While at least one private company, Willard Bishop Consulting (Barrington, III.), assembles PLU -based prices and quantities for industry use, no official statistics are assembled by the U.S. government. O ne of the principal industry publications, TheN atural FoodsM erchandiser ( $\mathrm{N}$ ew H ope Communications, Boulder, Colo.) , has revised its methodology for estimating retail sales of various food categories in recent years leading to discrepancies in the estimates of retail sales of fresh fruit and vegetables among other organic products. J ointly these problems in tracking the size and composition of fresh organic produce sales indicate how difficult it is to estimate the size of the market for fresh organic fruit and vegetables.

\section{Distribution of retail sales}

Where organic foods are soldsupermarkets, hypermarkets, green grocers, health food stores, etc. - matters becau se if they are only available in specialty stores, most consumerswould have to spend extra time and effort to purchase them. $\mathrm{H}$ ence, availability of organic foods at mainstream supermarkets is necessary for organic products to achieve a larger market share. Also, where organic foods are sold is important because consumers self-select by choosing particular retail food stores: shoppers choosing health food stores, for example, are more likely to purchase organics. Limited evidence suggests that some consumers decide prior to entering the store that they will purchase a particular organic item ( $H$ ansen and Sørensen, 1993; T hompson and Kidwell, 1998). If consumers who have previously purchased few or no organic food products are to become more frequent organic buyers, availability in convenient locationsand formats is necessary.

The distribution of retail sales of organic foods varies significantly from country to country. I n most E uropean countries at least half of organic food sales are at multiple retailers (Table 3 ). Germany is a notable exception where small-scale natural foods outlets still play an important role in retail sales; the apparent lack of promotion of organic foods by some retailers may be one reason why growth in the share of organic food sales seems to have reached a plateau in $\mathrm{G}$ ermany in recent years. The retail share of organic food sales in France is relatively low and the share of foods sold directly or at farmers markets is almost as high as that sold at multiple retailers ( 24 versus $28 \%$, respectively). Retail distribution in the U nited States differs from the European pattern because the emergence of natural foods supermarkets in the 1990s has propelled the growth of

T able 3. D istribution of retail sales of organic foods.

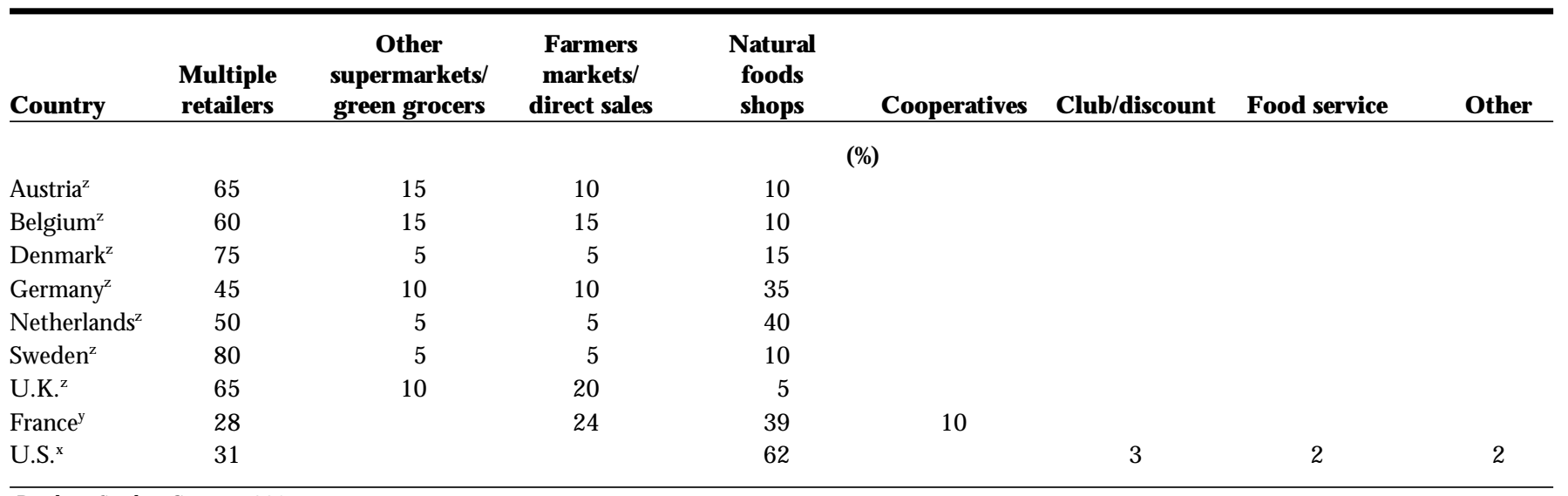

zProduce Studies Group, 1998.

yGauthier, 1997.

×O rganic Trade Association, 1998. 
retail sales of organic foods (Dunn, 1997). Partially as a result of increased competition by natural foods supermarkets in some U.S. metropolitan areas, mainstream supermarket chains have begun to stock and promote a wider array of organic foods (Weir, 1998). H owever, the proportion of organic food sales in mainstream supermarket chains is still relatively low. Industry observers in the Europe and the $U$ nited States agree that commitment to promote organic foods was and is essential for continued growth in retail sales. In the $U$ nited States, competition between the two largest natural foods supermarket chains, Whole Foods $\mathrm{M}$ arket (Austin, T exas) and Wild $O$ ats(Boulder, Colo.), has lead to increased sales of organic foods. In Denmark, the FDB chain (Albertslund, D enmark) made a commitment to promote organic foods with the result that retail sales grew significantly (M ichelson, 1996). Sweden's largest supermarket chain, ICA (Solna, Sweden), has made serious effortsin promoting organic productswhileG rönaKonsum (Stockholm, Sweden) , a Swedish consumer cooperative, claims to havethehighest share of organic foods of any supermarket in Europe (U .S. Embassy, Stockholm, 1998). In the last couple of years, upscale supermarkets like Waitrose
Supermarkets (London) and J. Sainsbury (London) in the U nited Kingdom as well as Tesco Stores (H ertfordshire, U.K.) now sell over 300 organic food items ranging from fresh fruit and vegetables to dairy and convenience foods (Waitrose Supermarkets, 1999; J Sainsbury plc, 1998; Tesco Stores Ltd., 1998). In Austria, Billa (Wiener Neudorf, Austria) and Spar (Salzburg, Austria) chains have actively promoted their own store brands of organic foods with apparent wide recognition by consumers (Zenner and Ziehlberg, 1998). Swiss retail chains $M$ igros (Fédération des coopératives M igros, Z urich, Switzerland) and C oop Suisse (Bâle, Switzerland), which account for over three quarters of retail food sales, promote more than 130 organic foods including baby foods, bread, dairy, sugar, tea, soft drinks and wine, all with the Bio-Label or organic certification (Wyler, 1998). Albert H eijn (Z aandam, TheN etherlands) recently announced the introduction their $\mathrm{AH}$ Biologisch brand of organic foods which includes a wide array of fresh and processed items, suggesting that organic food sales in The $\mathrm{N}$ etherlands are poised to grow (van der H arst-Collaris, 1998). Although market share in France still lags behind neighboring European countries, Carrefour (Paris), the sec- ond largest supermarket chain in France, now carries over 60 organic products (Gauthier 1998). Information on retail markets in Japan is sketchy, but it appears two large corporations with food manufacturing interests, Sumitomo (Tokyo) and $\mathrm{N}$ issho I wai (Tokyo), have special teams developing processed foodssuch asfrozen organic vegetableswhich will, in turn, need promotion at retail food venues (Seki, 1997). The commitment by mainstream supermarkets and manufacturers to promote a wider array of organic products is making a wider array of organic foods available to much larger segments of consumers at retail throughout the world.

In the U nited States and many European countries, food consumed away from homenow constitutesnearly half the value of all food consumed. As such, both food service and institutional buyers represent important potential channels for organic foods. In the U nited States, fresh organic fruit and vegetables have found apparently important niche markets among a select group of gourmet restaurants (Frithe, 1998). Some home delivery companies such as The F resh Kitchen (Boston) even offer baby, children, and adult organic foods. Anecdotal evidence from Europe also suggests that certain organic foods are begin-

T able 4. Estimated purchasing frequency of organic foods.

\begin{tabular}{|c|c|c|c|c|}
\hline \multirow[b]{2}{*}{ Country } & \multicolumn{3}{|c|}{ F requency of purchase } & \multirow[b]{2}{*}{ Year } \\
\hline & Regular & $H$ ave bought & N ever & \\
\hline Germany ${ }^{2}$ & 5 & 42 & 53 & 1984 \\
\hline Germany ${ }^{2}$ & 12 & 51 & 37 & 1989 \\
\hline Germany ${ }^{2}$ & 15 & 61 & 25 & 1994 \\
\hline Sweden ${ }^{y}$ & 14 & 19 & 41 & 1991 \\
\hline U.K. ${ }^{x}$ & 13 & 41 & 75 & 1993/1997 \\
\hline Spain $^{w}$ & 9 & 64 & 26 & 1997 \\
\hline France $^{v}$ & 6 & 23 & & 1995 \\
\hline The N etherlands" & 5 & 40 & 58 & $1990 / 1991$ \\
\hline D enmark ${ }^{\mathrm{t}}$ & & 30 & & 1994 \\
\hline Scotlands & & 29 & & 1993 \\
\hline \multicolumn{5}{|l|}{ U.S. region ${ }^{r}$} \\
\hline $\mathrm{N}$ ortheastern & & 37 & & 1997 \\
\hline $\mathrm{N}$ orth-central & & 24 & & 1997 \\
\hline Southern & & 26 & & 1997 \\
\hline Western & & 29 & & 1997 \\
\hline
\end{tabular}

\footnotetext{
${ }^{z}$ Alvensleben, 1997.

yBjerke, 1992 cited in $\mathrm{H}$ ansen \& Sorensen, 1993.

×D avies et al., 1995 (Regular, $\mathrm{H}$ ave bought); ACN ielsen, 1997 (N ever).

wG racia et al., 1998.

vG authier, 1996.

uvan der H arst-C ollaris, 1997 (R egular, H ave bought); H ack, 1993 (N ever).

tBredhal J ohansen, 1995 cited in Axelson, 1996.

'T regear et al., 1994.

rFood M arketing Institute/ PREVENTIO N , 1997.
} 
ning to appear in restaurants of many types and in various institutional settings. $\mathrm{M} C D$ onald's restaurants ( $\mathrm{O}$ ak Brook, III.) in Sweden offer organic milk and coffee; one quarter of the Swedish municipalities haveschoolsor hospitals with some organic foods served; and train restaurant cars feature organic milk and coffee (U.S. Embassy, Stockholm, 1998). Swissair (Zurich, Switzerland) and Lufthansa (Cologne, Germany) business class food servicesnow offer organic farefor passengers. Organic chocolate, tea, coffee, and even white sugar are available in many countries. Q uantifying the value of organic foods consumed through food service and institutional channels is exceedingly difficult but consumers' exposure to these organic foods in various public places makes them more aware of the widening array of organic food products available.

\section{Characteristics of consumers buying organic foods}

Although the types of consumers likely to be regular purchasers of organic foods vary considerably across countries, the proportion of consumers regularly buying organic foods is relatively small, usually less than $15 \%$ of shoppers (T able 4). Evidence from the mid-1980s to the mid-1990s in Germany suggests that more consumers have apparently become regular purchasers. Yet in France and The $\mathrm{N}$ etherlands the proportion of regular buyers of organic foods is currently quite small. These figures suggest that even in the largest organic food markets throughout the world, anywhere from one-fourth to three-fourths of consumers have never purchased organic foods of any sort. Even those consumers professing to be regular consumers still account for a relatively small proportion of retail sales as the respective market shares of organic foods in those countries indicate.

Consumers more likely to purchase organics do not always fall into well defined categories across countries. In the U nited States, there are several consumer segmentswhich seem to be more likely to purchase organics (Thompson, 1998). Socioeconomic and demographic factors such as income, age, gender, education, marital status, and presence of children in the household may be examined to char- acterize consumers more likely to buy organic food. Although the joint evidence of U.S. academic and industry studiesdoesnotal ways coincide, studies suggest a bimodal pattern associated with income and organic food purchases: selected lower and higher income groupsmay be more likely to buy organicfoodswhilemiddleincomeconsumers are less likely to do so (The Packer, 1998; H artman Group, 1996). Some evidence suggests, however, that certain high income consumers are sensitive to organic price premiums (Baker and Crosbie, 1993; Thompson and Kidwell, 1998). Bimodal behavior with respect to age also occurs: consumers in the 18 to 29 and 40 to 49 years of age brackets are most likely to have bought organic produce (The Packer, 1998). The former group apparently is more concerned with environmental issues associated with organic foods whereas the latter purchases organic foods more for health reasons ( $\mathrm{H}$ artman Group, 1996; Food M arketing I nstitute/ PREVENTION, 1997). Gender and marital status generally are poor predictors of likelihood of purchasing organicfoods but one segment of consumers, denoted the T rueN atural sby theH artman Group (Bellevue, Wash.), has a higher than average percentage of divorced women. In some cases, higher levels of educational attainment are positively correlated with higher likelihood of purchasing organic foods ( $\mathrm{H}$ artman Group, 1996; Food M arketing Institute/ PREVEN TIO N, 1997; Swanson and L ewis, 1993). H owever, somestudies have found no evidence linking educational attainment with organic food purchases (Jolly, 1991; Goldman and Clancy, 1991). A few studies indicate that attainment of postgraduate or professional degrees may even diminish the likelihood of purchasing organic foods (Byrne et al., 1991; Thompson and Kidwell, 1998). Finally, presence of children in thehousehold likelyincreases the probability of purchasing organic foods (Thompson and Kidwell, 1998) but few studies have considered more than the effects of household size irrespective of family members' ages on decisions to buy organic foods. In very

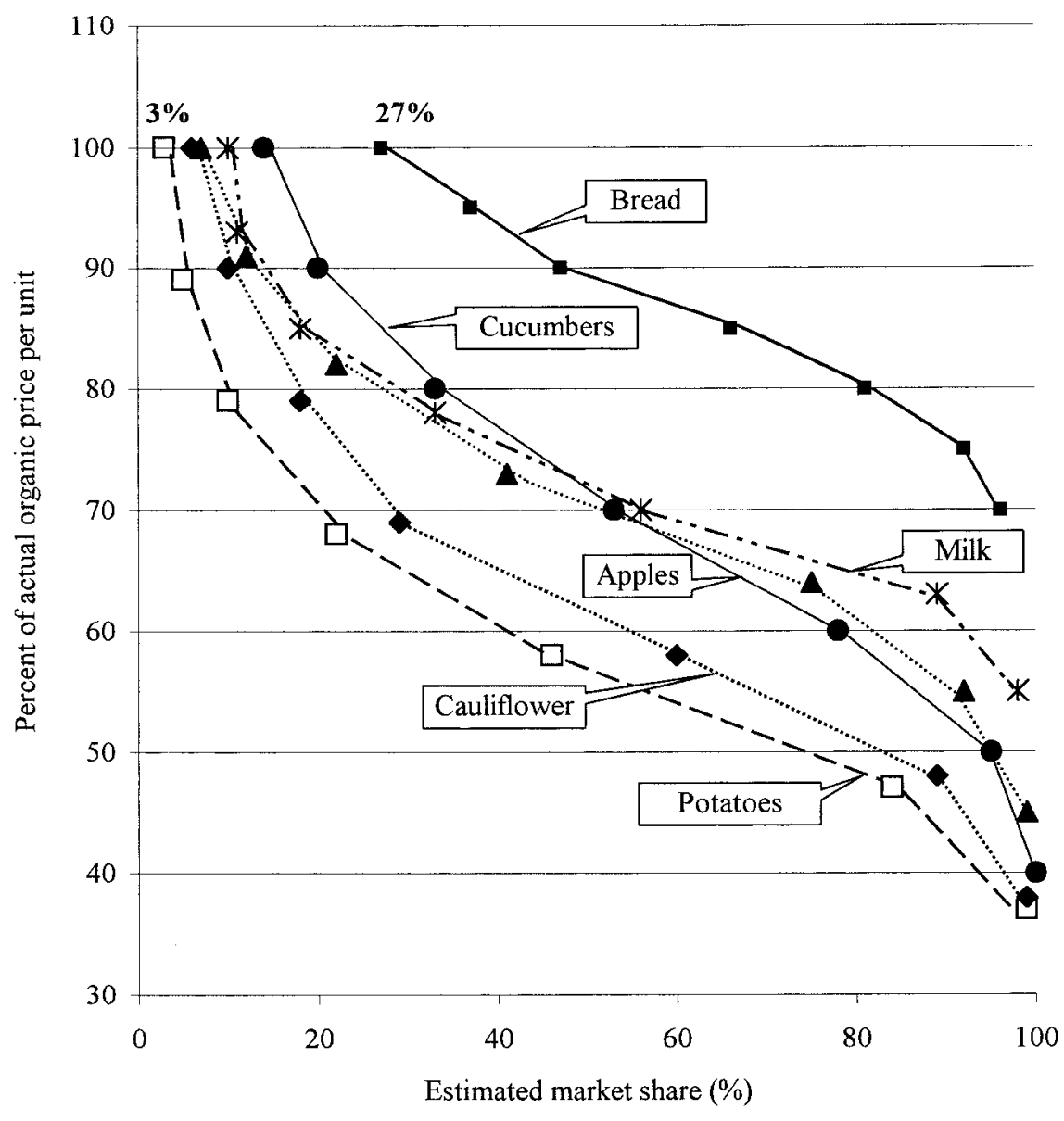

Fig. 1. Estimated market share of Dutch horticultural products (calculations from data in Baggerman and $H$ ack, 1992). 


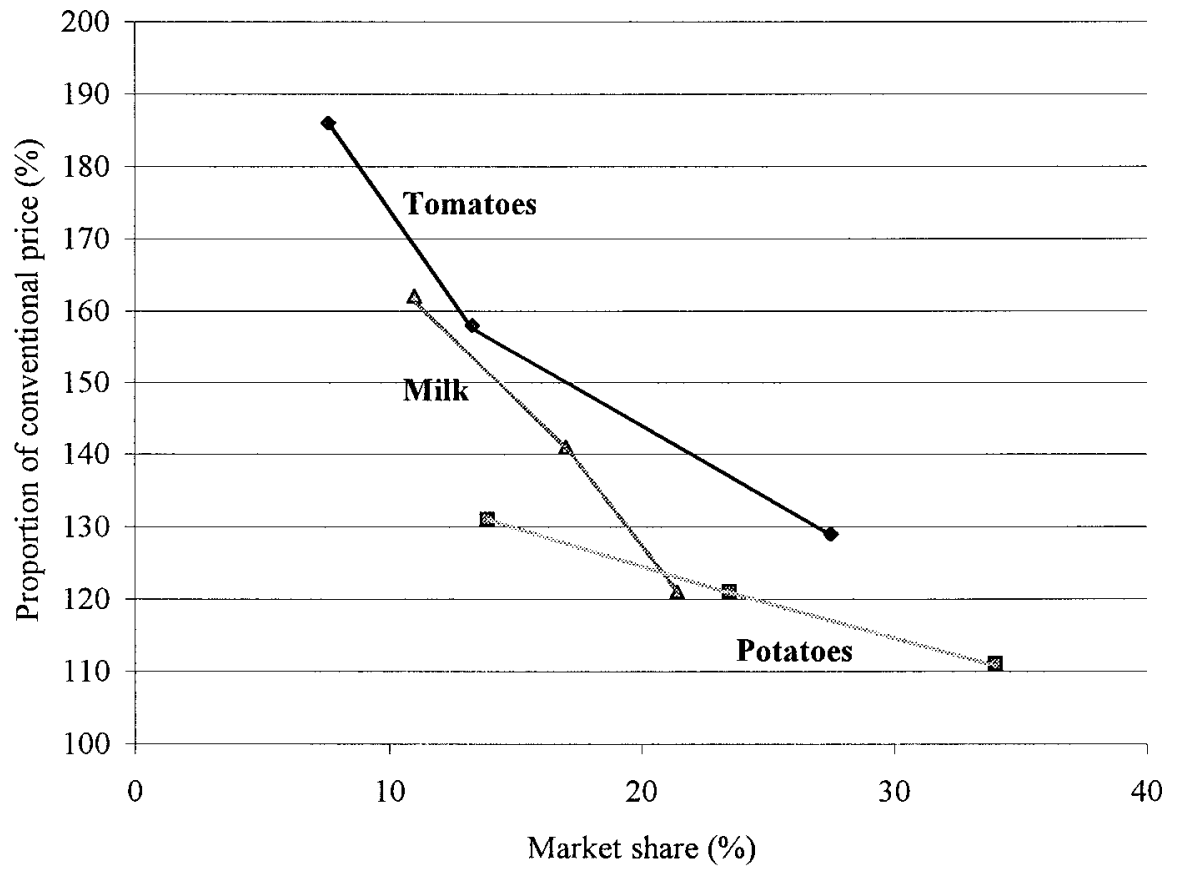

Fig. 2. Experimental market share of $D$ anish organic foods ( $H$ ansen and Sørensen, 1993).

broad terms, two important segments likely to purchase organic foods are 1) younger, single consumers with low household incomes and 2) middle age consumers with higher household incomes, in some cases with children living at home.

European consumers of organics display some similarities to their U .S. counterparts. In Germany, for example, two groups are more interested in organicfoods: 1) young peoplewith strong criticisms of conventional food supplies and 2) older people with strong health consciousness (Alvensleben and Altmann, 1987). Related research from Germany posits that income and prices play less of a role in identifying organic consumers than do consumer attitudes (Fricke and Alvensleben, 1997). In N orthern I reland, the group most likely to consume organics is comprised of women between the ages of 30 to 49 years with children and high household incomes (D avies et al., 1995). In contrast to the German research, these $\mathrm{N}$ orthern I reland results suggest indirectly that prices and incomeareimportant determinantsin identifying organic consumers especially when childrens' health concerns are present.

Indirect evidence concerning the market share of babyfoodsin theU nited States corroborates the importance of children in a household's decision to purchase organic foods. In the U nited States, while about $1 \%$ of total retail food sales in 1995 were organic foods, baby foods accounted for $2.5 \%$ of baby foods sold in U.S. supermarkets ( $\mathrm{H}$ arris, 1997). In Sweden, the ICA retail chain reports that $7 \%$ of the baby foods sold were organic, about twice the market share of organic products in any other processed food category of ICA (U .S. Embassy, Stockholm, 1998). This anecdotal evidence suggests that some countries may expect substantial increasesin futureorganic baby food sales. France, for example, currently has the highest per baby consumption of baby foods in the world at $95 \mathrm{~kg}(209 \mathrm{lb})$ per baby (Sharpless and Gauthier, 1998). As organic food purchases increase in France, purchases of organic baby foods will likely increase markedly.

\section{Willingness to pay for organic foods}

$M$ any studies around the world have attempted to estimate consumers' willingness to pay more for organic foods. The popularity of willingness-to-pay studies likely owes more to the paucity of data about actual consumer behavior than it does to the accuracy of the methods available for estimating how much consumers are willing to pay. D espite their shortcomings willingness-to-pay studies have been conducted in the U nited States (M isra et al., 1991; Weaver et al., 1992), The N etherlands (Baggerman and $H$ ack, 1992), Spain (G racia R oyo et al., 1998), I taly (Vastola, 1997), Denmark ( $\mathrm{H}$ ansen and Sørensen, 1993), and N ew Zealand (Saunders, 1999). Some studies query the willingness to pay for predetermined price premiums while others use various hypothetical questioning techniques to arrive at premiums. As would be expected, habitual buyers of organic foods consistently are willing to pay higher premiums than are consumers buying less frequently or never ( $\mathrm{H}$ ack, 1993; G racia Royo et al., 1998). L imited evidence also suggests that some consumers are willing to pay higher premiumsfor fruit and vegetablesthan for any other food category except beef (G racia et al., 1998).

By systematically varying the willingness-to-paylevelsover awiderange, researchersareableto generateaschedule of willingness to pay akin to a traditional demand curves (Fig. 1). Their schedules of willingness to pay can give crude estimates of how market shares may grow as organic prices drop. Baggerman and Hack (1992) generated such willingness-to-pay estimates for four horticultural products- potatoes (Solanum tuberosum L.), apples [M alussylvestris(L.) M ill.], cauliflower (Brassica oleracea $L$. Botrytis G roup), and cucumbers ( $\mathrm{Cu}$ cumissativusL.) - as well as for staples such as milk and bread. Their results indicated that estimated market shares for horticultural products at actual organic prices were generally lower than for milk (10\%) and bread (27\%). $\mathrm{H}$ owever, all their estimated market shares based on willingness-to-pay answers exceeded actual market shares for the same products, thereby illustrating the upward bias of many willingness-to-pay methodologies.

Studies of willingness to pay have been augmented by experimental studies which compare purchases in experimental situationswith each participant's stated willingness to pay. $\mathrm{H}$ ansen and Sørensen conducted an experiment in which Danish shoppers were given money to purchase organic or conventional skim milk, potatoes, and tomatoes (Lycopersicon esculentum M ill.) displayed in a room apart from the rest of the store. The volunteer shoppers had already decided to shop at the selected FDB outlets which had an enhanced array of organic products compared to other storesat thetime. Because of their prior store choice, this sample of shoppersmight not accurately represent other 
Organic potatoes: prior market share $=26 \%$

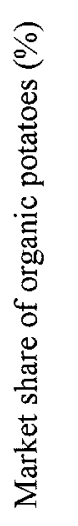

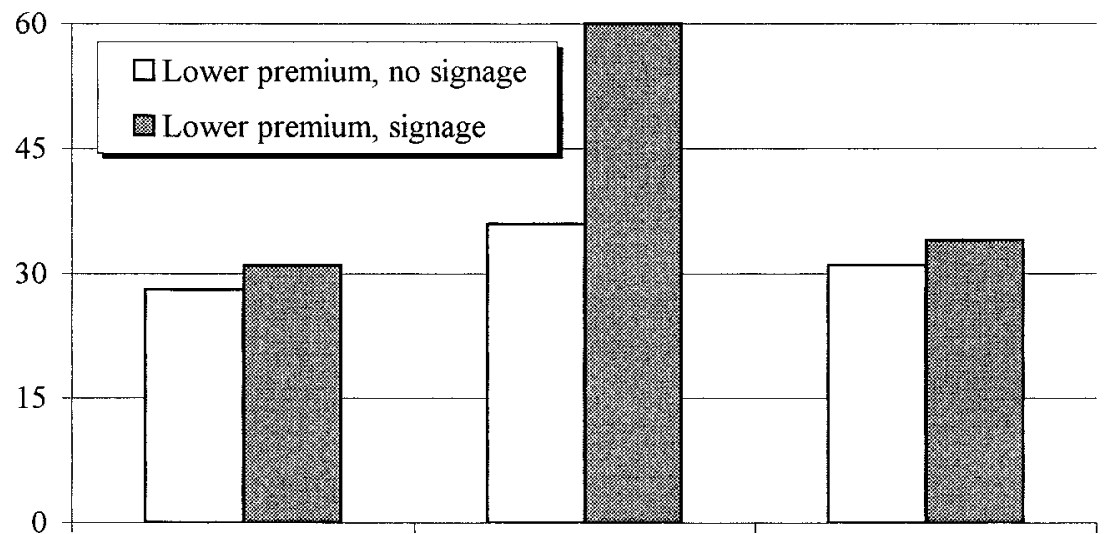

Week 1
Week 2

Week 3

Organic carrots: prior market share $=14 \%$

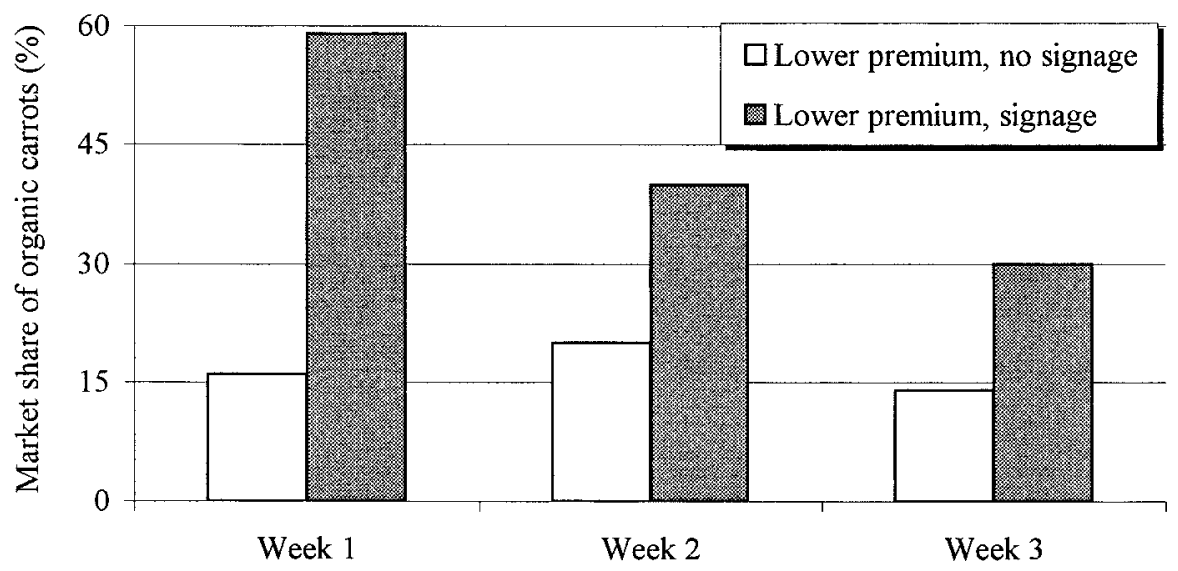

Fig. 3. Actual market shares of Swedish organic produce (Björkman, 1994).

D anish consumers. N onetheless, their experimental results support two important conclusions. First, experimental purchases corroborate that stated willingness to pay often exceeds actual payment behavior in an experimental setting. Experimental estimates placed the market share of organic skim milk at $11 \%$ while actual share in FD B stores at the time was 12\% estimates of willingnessto pay for organic skim milk placed market shareat higher percentages. Second, and perhapsmoreimportant, shoppersdisplayed pronounced sensitivity to decreases in organic prices: the market share of organic skim milk would al most double from 11 to $21.4 \%$ if the price premium were lowered from 62 to $21 \%$ of the conventional counterpart. Q uantitiespurchased of organic potatoeswere even more sensitive to price reductions: organic market share could beincreased from 13.9 to $34 \%$ if price premiums were reduced from 31 to $11 \%$ of conventional prices. Figure 2 displays the respective market shares for the three products at the price premiums used in theexperiment. Theimportant implication of these experiments is that even with frequently purchased, habit-determined items like milk, reductions in organic price premiums might induce sizable increases in market share at re tail. For fresh horticultural products such as potatoes and tomatoes, reductions in price premiums could lead to significant increases in market share.

A few market experiments have been conducted to observe how consumersrespond in a controlled environment to actual changes in organic price premiums (Björkman, 1994; R eicks et al., 1997). In Sweden, reductions in organic price premiums alone and in conjunction with increased advertising and in-store signage were measured for fresh potatoes and carrots (Daucus carota L.) (Björkman, 1994). Björkman (1994) arranged for a retail outlet in Södemalen, Stockholm to lower price premiums on organic potatoes and carrotsfor 3-week periods. D uring the first 3-week period, only price premiums were reduced from an average of 55\% to just $25 \%$ of the conventional potatoes and carrots. An interim period of 5 weeks elapsed before a subsequent 3week period in which organic price premiums were reduced again to $25 \%$ of conventional and in-store signage was simultaneously increased. The results were not consistent across the two produce items: more prominent signage increased market share of carrots more notably in all weeks than it did for potatoesalthough differencesin signage effects between the two products were not tested for statistical significance(Fig. 3). Lowering prices required about 1 week before quantities sold increased; for both carrots and potatoes the effects of lowering prices did not appear to be sustained through thethird week of the experiment. While a number of factors could have caused the declining effect of lowered premiums and signage in the third week of the experiment, one hypothesis consistent with the behavior observed is that shoppers who had not previously purchasestheseorganicproducts were attracted by either lower relative price or signage, or both, but did not continue with weekly purchases of those produce items. Both carrots and potatoes can be stored for more than 1 week so that they may be purchased at intervals of more than a week.

The effects of point-of-purchase signage on the sales of 14 organic food items in both upscale and a discount/ warehouse stores were tracked in the M inneapolis/ St. Paul, M inn., area (Reicks et al., 1997). Not only did increased signage have differential effects across organic food items, but the effects of signage differed across thetwo types of stores; sales of a larger array of items were augmented with signage at the discount/ warehouse stores than at the upscale stores. The demographic profilesofcustomersrecognizing signage also varied: those shoppers most likely to recognize new signage were young people, women, and thosehaving larger household sizes. The Stockholm and M inneapolis/ St. Paul studies corroboratetheindustry consensusthat without 
activepromotion, simply having awider array of organic products available at mainstream retail venues will not be sufficient to enhancethemarket share of organic foods. What is less clear, however, from these two studies is how important reducing pricepremiumsmay be in stimulating organic food sales throughout the world. Reicks et al. (1997) did not analyzechangesin prices whereas Björkman (1994) observed prices changes for just two fresh products during relatively short 3-week periods.

\section{Price premiums for organic foods}

Reliable information of price premiums for organic foods is exceedingly difficult to obtain for a number of reasons. First, many products are of recent vintage so that sales data simply did not exist before this decade. Second, until the past 5 years, many fresh and processed organic foods were sold outside mainstream supermarkets so that scanner datacompaniesdid not capturesales information. N ow scanner data are being collected but these data must be purchased at relatively high cost from companies like ACN eilsen (Stamford, Conn.) and IRI (I nformation Resources, Inc., Chicago, III.). Even with the advent of usable data series for scanned products, data for many fresh produce items not bearing U PC codes are still sparse.

Some very tentative hypotheses about retail pricepremiumscan bemade on the basis of the few isolated reports publiclyavailablethroughout the world (Table 5). Retail price premiums on fresh organic fruit and vegetables as well as frozen vegetables appear to be high relative to premiums for other processed organic foods. Price premiums in excess of $100 \%$-double the conventional price-appear commonfor both frozen and fresh produce. D ata are insufficient for comparing premiums of horticultural and nonhorticultural items in most countries but in Sweden the premiums for nonhorticultural products tended to be smaller. Anecdotal evidencefor isolated productselsewhere tendsto corroborate these findings. For example, in TheN etherlands, L angezaal (1996) reported that biodynamic (organic) cheese is $60 \%$ costlier than the conventional counterpart. Crutchfield et al., cited in Glaser et al. (1998), reported that monthly average price premiums for fresh organic broccoli (Brassica oleracea L. I talica Group) in theU nited States rose from 77 to $145 \%$ in theperiod from 1992 to 1995 . Whole-

T able 5. R etail price premiums for organic foods as a percentage of conventional prices.

\begin{tabular}{|c|c|c|c|c|c|c|}
\hline \multirow[b]{2}{*}{ Food } & \multirow{2}{*}{$\begin{array}{c}\text { Sweden }^{2} \\
1998 \\
?\end{array}$} & \multicolumn{4}{|c|}{ U.S. } & \multirow{2}{*}{$\begin{array}{c}\text { Netherlands } \\
1991 \\
? \\
\end{array}$} \\
\hline & & $\begin{array}{c}1996 \\
\text { N ationaly } \\
\end{array}$ & $\begin{array}{c}1995 \\
\text { T ucson }^{\mathrm{x}} \\
\end{array}$ & $\begin{array}{c}1992 \\
\text { Denver }\end{array}$ & $\begin{array}{c}1991 \\
\text { Tucson }^{u} \\
\end{array}$ & \\
\hline \multicolumn{7}{|l|}{ Fresh } \\
\hline Apples & & & & 143 & 18 & 120 \\
\hline Golden D elicious & 98 & & & & & \\
\hline Red D elicious & & & 42 & & & \\
\hline Broccoli & & & 81 & 135 & & \\
\hline Cauliflower & & & & & & 167 \\
\hline Carrots & & & 175 & 125 & 86 & \\
\hline Lettuce & & & & 195 & 16 & \\
\hline Green leaf lettuce & & & 91 & & 61 & \\
\hline Tomatoes & & & 45 & & 128 & \\
\hline Potatoes & & & & 159 & 31 & 171 \\
\hline Cucumbers & & & & & & 150 \\
\hline \multicolumn{7}{|l|}{ Frozen } \\
\hline Broccoli & 139 & 164 & & & & \\
\hline Peas & 0 & 230 & & & & \\
\hline Green beans & & 174 & & & & \\
\hline Sweet corn & & 96 & & & & \\
\hline French fried potatoes & & 194 & & & & \\
\hline Canned & & & & & & \\
\hline Tomatoes & 125 & & & & & \\
\hline \multicolumn{7}{|l|}{ O ther Foods } \\
\hline O range marmalade & 10 & & & & & \\
\hline Peanut butter & 39 & & & & & \\
\hline Bread & 13 & & & & & 43 \\
\hline Cheese & 11 & & & & & \\
\hline Yogurt & 24 & & & & & \\
\hline Spaghetti & 37 & & & & & \\
\hline Ketchup & 32 & & & & & \\
\hline Coffee & 18 & & & & & \\
\hline
\end{tabular}

zU .S. E mbassy, Stockholm, 1998.

yG laser et al., 1998.

xThompson and Kidwell, 1998.

vSparling et al., 1992.

uConklin et al., 1992.

tBaggerman and H ack, 1992. 
sale price premiums in Boston for organic carrots and mesclun are of similar magnitudes, ranging from as low as $8 \%$ to as high as $157 \%$ (G reene and $C$ alvin, 1997).

The ranges or average price premiums reported for many countries are conspicuously lower than many of the premiums displayed in Table 5 . Typical figures are Sweden, 38.6\%( average of first column in T able 5); $\mathrm{N}$ etherlands, 20 to $50 \%$ (van der $\mathrm{H}$ arstCollaris and Scandurra, 1997); Austria, 20\% (K rucsay, 1996); Australia, 12.5 to $60 \%$ (H udson, 1996); and France, 20 to $100 \%$ (G authier, 1996). Some studies do recognize, however, that premiums on fresh fruit and vegetables may fluctuate to as high as $200 \%$ depending on season and weather events(ProduceStudiesG roup, 1998). What averages and ranges of price premiums tend to mask are apparently higher premiums for fresh and even frozen fruit and vegetables.

Lower organic yields and more volatility in organic supply are likely causes for the relatively large price premiums for fresh organic produce. Yields for organic fruit and vegetables tend to belower than for their conventional counterparts especially in years following transition of land from conventional to organic production. The notorious f.o.b. (free on board) price volatility experienced by conventional growers when adverse weather strikes is likely exacerbated for organic farmers who cannot take recourse to agrochemicals to mitigate the impacts of adverse weather, pests, and diseases. Theopportunitiesto diversify spatially, as many conventional grower-shippers do (Wilson et al., 1997), may be fewer because organic farm land typically requires some years in transition before produce can be certified organic. Lastly, import costs of out-ofseason produce items are likely to be relatively high because there are fewer organic than conventional suppliers internationally and organic certification costs for imports can be considerable (L ohr, 1998). Preservation of organic products along the marketing channel from farm gate, handling, processing, and delivery can also contribute to higher premiums at retail.

Theimportant implication of relatively high price premiums for organic foods in general and organic fruit and vegetables in particular is that they are simply too expensive for the majority of consumers. Even those consumers who identify themselves in surveys as potentially interested in organic foods do not actually purchase organic products because there are cheaper alternatives. There are only two econometric studies based on scanner data of actual buying behavior in the $U$ nited States which tests the hypothesis that high price premiums inhibit purchases of organic foods (Glaser et al., 1998; Glaser and Thompson, 1999). Both studies use aggregate U .S. data from AC N ielsen for 1990 to 1996. G laser et al. estimated single-equation demand relationshipswhile G laser and Thompson estimated a demand system for pairs of organic and conventional frozen green beans (Phaseolus vulgaris L.), green peas, corn (Zea mays L.), and broccoli. In the latter study, ownprice responseto reductionsin organic priceswasconsiderablewith own-price elasticities ranging from -1.630 to 2.268. These elasticities indicatethat a $10 \%$ reduction in, say, organic broccoli would result in a $22.68 \%$ increase in consumption from average levels during the 1990-96 sample period. By contrast, own-price elasticitiesfor conventional frozen vegetables were smaller-from-0.596 to-1.043-and not al waysstatistically significant. These elasticity estimates mean that as the price of organic frozen vegetables decline, quantities consumed will more than proportionally increase, resulting in higher market shares of organic frozen vegetables. $\mathrm{H}$ ence, at least for frozen vegetables, high organic price premiums are a serious obstacle to increased organic market share.

\section{Prospects for growth in demand for organic foods}

Future growth in the demand for organic products will hinge on how much pricepremiumsfor organic foods can be reduced. Theinitial obstaclesto growth-the consistent availability of a wide array of organic products in convenient locations and consumers' familiarity with those products-are beginning to be surmounted in the larger markets throughout the world. As more organic products of consistent quality have become available in mainstream supermarketsand through food service channels, the principle barrier to continued growth is high price. Lower prices will induce more frequent purchases of a wider array of products by those consumers al ready buying some organic items. And lower prices will attract new consumers who previously found organic foods too expensive. Both phenomena are necessary for growth in the demand of organic foods.

Several supply and demand factors are critical in determining how much prices can be reduced.

\section{Supply conditions affecting price premiums}

Seasonality in production presents a serious hurdle to reducing organic price premiums, particularly for highly perishable fresh fruit and vegetables. $M$ any conventional grower-shippers diversify geographically, whether it be within a single country or throughout the world, in order to provide produce continuously throughout theyear. The more distant are production regions, the more costly coordination of yearround production becomes especially when production conditions, business practices, and languages change from place to place. The costs of sourcing perishables year-round could be even higher for organic produce because there are relatively fewer growers from which to choose and certified production areas are relatively smaller. Further, certification regulations also differ across areas and countries making international transactions even costlier. Shipping and distribution costs for organic operations will be higher than their conventional counterparts due to greater losses in transit from spoilage and diseconomies of scale for smaller operations. All thesefactors, in addition to lower yields and higher volatility in supplies for organic products, suggest that price premiums for fresh fruit and vegetableswill continue to be large.

For countries with limited opportunities to diversify domestic production of fresh fruit and vegetables, these obstacles to reducing price premiums are more formidable. In the $U$ nited Kingdom, for example, about $70 \%$ of all organic foods are imported ( $C$ anadian $\mathrm{H}$ igh Commission, 1998), alarge portion of which are presumably imports of out-of-season fresh produce items. If greenhouse production were compatible with organic production methods, domestic production capacity could be augmented but winter production in greenhousesiscostly. If, 
as is more likely, greenhouse production cannot be made compatible with organic production techniques, UK consumers will have to rely on imports of organic fresh fruit and vegetables exclusively for subtropical and tropical items and for other itemsduring many months of the year when domestic production is not possible. Advances in fresh processing technology may mitigate these problems in the future but for now freezing, canning, drying, and other processes are the only alternatives to fresh products especially for fruit.

\section{Marketing conditions affecting price premiums}

Retail prices of organic foods depend on the costs of production, packaging, marketing, and distribution. But retail organizations such as supermarket chains also have different pricing mechanisms depending not only on cost of acquisition of goods but also the types of food items considered as well as their business strategies. $\mathrm{H}$ ypermarkets, for example, typically follow everyday, low-price schemes based on scale economies in acquisition, logistics, and management of information. G reen grocers, by contrast, may follow simple markup rules for determining retail prices. Supermarkets typically advertise certain products each week as loss-leaders in an attempt to lure customers into the store.

H ow large organic price premiums are at retail is affected both by costs and pricing strategies. Price premiums are high in some mainstream $U$.S. supermarkets because the labor and management costs associate with their promotion are relatively high (Weir, 1998). Somesupermarketshave ado pted a policy of attempting to limit organic price premiums to fixed upper limits. Limiting price premiums may be a viable short-run strategy for attracting someconsumersbut ultimately competition for shelf space will drive most chains to make retail prices reflect their costs of acquisition. This means that economies of scale in buying, distribution, and management are the most likely sources for reducing price premiumsby retail organizations.

\section{Governmental intervention affecting price premiums}

Some observers argue that retail prices of conventional foods are lower precisely because the costs of negative externalities resulting from conventional production practices are not included in their market prices ( $L$ ataczLohmann and Foster, 1997). This phenomenon is an example of market failure in which governments may be justified in intervening to make private costs more closely reflect social costs. $M$ arket failure and other arguments have been advanced in the European $U$ nion and some individual European countries for providing subsidies of different typesto promoteorganic production and consumption. The most common type of subsidy is to farmers for converting land to organic production (M ichelson, 1996). Subsidies for generic advertising have al so been pursued in Denmark, The $\mathrm{N}$ etherlands, and France among others. To the extent these subsidies lower the retail prices of organic products, they foster growth of the organic food market. M ichelson (1996) argues that government subsidies of this sort in conjunction with the commitment by industry officials to promote organic foods has been the key to rapid growth of the sector in D enmark.

\section{Conclusions}

The availability of data to analyze consumer demand for organic foods are spotty and scarce because only recently have organic foods been sold in supermarkets where scanner data are collected. At present, much of the information used to analyze consumer demand is by necessity circumstantial and indirect, often with consumers' self-reported behavior rather than independent observation of their behavior in actual markets.

Throughout the world, the early consumers of organic foodswerethose peopleresiding in upper-incomecountries who were willing to pay extra for organic foods. Their motivations for paying extra were many: environmentally friendly production methods; ingestion of lower levels of pesticides in foods; foods grown by locally owned, small family farms; less exposure of farm workers to pesticides; and perceived better flavor or nutritional content, among others. But the proportion of the populations holding these concerns strongly enough to pay extra is quite small. $O$ thers who may share these concerns have been reluctant to pay extra. Still others do not share these concerns or are simply not cognizant of them. The point isthat for all but a select few, relative prices of organic and conventional food items are the most important consideration in buying food. Without significant reductions in retail price premiums, the market share of organic foods will remain very small.

Q uantitative estimates of how much consumers in the aggregate are likely to respond to lower price premiums are sorely lacking. While many surveys havefound that consumersare willing to pay more for organic foods, actual behavior belies their responses. Economic experiments and limited retail evidence suggest that the increase in organic purchases resulting from lower price premiums at retail are substantial although when price premiums are as high as $200 \%$, small reductions in those premiums have little detectable effect. Reductions of retail price premiums in conjunction with augmented signage and promotion have greater effects than price reductions alone. If occasional buyers of organic foods are to become more regular purchasers of a wider variety of items, and if new buyers of organic foods are to become first-time purchasers, price premiums at retail must fall. O nly then will the market share of organic foods throughout the world increase significantly beyond current levels.

\section{Literature cited}

ACNielsen. 1997. ACN ielsen survey reveals only one in four ever go organic. ACN ielsen, O xford, England. 8J an. 1999. http:/ / acnielsen.com/ acn/ press/ unitedki/ 970911.htm.

Alvensleben, R.v. and M. Altmann. 1987. $D$ eterminants of demand for organic food in Germany. Acta H ort. 203:235-242.

Alvensleben, R.v. 1997. E cological aspects of food demand: the case of organic food in Germany. I n.: AI R-CAT 4th Plenary M eeting: $\mathrm{H}$ ealth, E cological and Safety Aspects in Food Choice 4:68-79. 8 Jan. 1999. http://www.uni-kiel.de:8080/ Agraroekonomie/Abteilungen/ agrarmarketing/ Lehrstuhl/ oekopro.htm.

Axelson, L.E. 1996. Demand and supply factors on the market for organic vegetables: The case of Sweden. Acta H ort. 429:367-375.

Baggerman, T. and M.D. H ack. 1992. C onsumentenonderzoek naar biologische produkten: $\mathrm{H}$ oehe marktaandeel vergroot 
kan worden. Insituut voor Consumentenonderzoek, L andbouwEconomisch Insituut, $\mathrm{D}$ en $\mathrm{H}$ aag, The $\mathrm{N}$ etherlands.

Baker, G.A. and P.J . Crosbie. 1993. M easuring food safety preferences: I dentifying consumer segments. J. Agr. ResourceE con. 18:277-287.

Björkman, Pär. 1994. Prisets och exponenringens Effekt på försäljningen av ekolgiskt odlade produkters: En butiksstudie över morot och potatis. Sveriges Lantbruksuniversitet, Examensarbete. Alnarp, Sweden.

Byrne, P.J ., U.C. T oensmeyer, C.L. German, and H.R. M uller. 1991. A nalysis of consumer attitudes toward organic produce and purchase likelihood. J. Food Distrib. Res. 22:49-62.

Canadian High Commission. 1998. Trends: Food in the U nited Kingdom. Can. H igh Commission Commercial Econ. Div., L ondon, U .K. 12 Jan. 1999. http:/ / atn-riae.ag.ca/ public/ htmldocs/ e2166.htm.

Conklin, N., G. Thompson, and L. Riggs. 1992. Price and quality differentials in organic and conventional produce markets. Final Rpt. U SDA-Agr. M ktg. Serv., Coop. Agreement 12-25-A3202.

Davies, A., A.J. Titterington, and $C$. Cochrane. 1995. Who buys organic food? A profile of the purchasers of organic food in N orthern I reland. Brit. Food J. 97:1723.

Dunn, J.A. 1997. AgriSystems International reportscertified organic production in the United States: $\mathrm{H}$ alf a decade of growth. AgriSystems I nternational, Wind Gap, Pa.

Eastwood, D.B. 1997. Information technology and fresh produce: A case study using store level scan data to analyze sales. The R etail Food I nd. Center, U niv. M inn., St. Paul, Working Paper 97-04.

Food $M$ arketing I nstitute and PREVEN TION Magazine. 1997. Shopping for health 1997: Balancing convenience, nutrition and taste. Princeton Survey Res. Assoc., Princeton, N.J.

Fricke, A. and R.v. Alvensleben. 1997. Consumer attitudes towards organic food and an application of cohort analysis1984-1989-1994, Arbietsberichte, L ehrstuhl für Agrarmarketing, I nstitut für Agrarökonomie, Christian-AlbrechtsU niversität, Kiel, Germany.

Frithe, B. 1998. H aute produce: Fruits and vegetables take center stage in restaurants. Produce Bus. 14:12-16.

Gauthier, R. 1996. O rganic foods in France update. U SD A Foreign Agr. Serv. Volun- tary Rpt. AGR \#F R6094, Wash., D.C.

Gauthier, R. 1997. French demand for organic food is skyrocketing. U SD A F oreign Agr. Serv. Voluntary Rpt. AGR \#FR 7060, Wash., D.C.

Gauthier, R. 1998. U pdate on French organic consumers and market. USDA Foreign Agr. Serv. Voluntary Rpt. AGR \#FR 8036, Wash., D.C.

Glaser, L., B. Krissoff, A. Lengyel, and K. Sheeran. 1998. Demand for frozen vegetables: A comparison of organic and conventional products. U SD A E con. Res. Serv., Veg. Spec. Situation and O utlook VGS276, 23-31 N ov., Wash., D.C.

Glaser, L. and G.D. Thompson. 1999. $D$ emand for organic and conventional frozen vegetables. Selected paper, presented at annual meeting of the Amer. Agr. Econ. Assn., N ashville, Tenn., 8-11 Aug. 9 Sept. 1999.http:// agecon.lib.umn.edu/.

Goldman, B.J . and K.L. Clancy. 1991. A survey of organic produce purchases and related attitudes of food cooperative shoppers. Amer. J. Alt. Agr. 6:89-96.

Gracia Royo, A., J.M. Gil Roig, and M. Sánchez García. 1998. Potencial de mercado de los productos ecológicos en Aragón. Servicio de Investigación Agroalimentaria, Diputación General de Aragón, Zaragoza, Spain.

Greene, C. and L. Calvin. 1997. “O rganically grown" vegetables: U .S. acreage and markets expand during the the 1990s. U SD A E con. Res. Serv., Veg. Spec. Situation and O utlook VGS-271, 19-23 Apr.

H ack, M .D . 1993. O rganically grown products: perception, preferences and motives of D utch consumers. ActaH ort. 340:247253.

H ansen, J.K. and H.C. Sørensen. 1993. The importance of price for the sale of ecological products. Ctr. M arket Surveillance, Res. Strategy Food Sector W orking Paper 13, Aarhus, Sweden.

H arris, J.M. 1997. Consumers pay a premium for organic baby foods. FoodR eview 20:13-16.

$\mathrm{H}$ artman G roup. 1996. Food and the environment: a consumer'sperspective, phase I. H artman Group, Bellevue, Wash.

H udson, R. 1996. The domestic market for Australian organic produce: an update. $\mathrm{H}$ assall \& Associates Pty Ltd. Report for Rural I ndustriesR esearch \& D evelopment Corporation, RIRD C R esearch Paper No. 96/ 1. Rural Industries Research \& D evelopment Corporation, Barton, Australian Capital Territory, Australia.

International Trade Centre. 1999. Organic food and beverages: world supply and major E uropean markets. U nited $\mathrm{Na}$ tions C onference on Trade and D evelopment, W orld T rade O rganization, G eneva, Switzerland.

J Sainsbury plc. 1998. Environment report. 8 Feb. 1999. http:/ / www.jsainsbury.co.uk/ company/ environment. html.

Jolly, D .A. 1991. D eterminants of organic horticultural products consumption based on a sample of C alifornia consumers. Acta H ort. 295:141-148.

Kortbech-O lesen, R. 1998. Export potential of organic products from developing countries. I ntl. Fed. O rg. Agr. M ovements, '98 Argentina, 1st Intl. Sem., O rganics in the supermarket, $15 \mathrm{~N}$ ov. 1998, M ar D el Plata, Argentina.

Krucsay, W. 1996. Organic agriculture and food in Austria. U SDA Foreign Agr. Serv., AGR \#AU 6055, Wash., D.C.

L angezaal, C.J.M . 1996. O rganic foods in the N etherlands 1996. U SD A Foreign Agr. Serv., AGR \#N L 6152, Wash., D.C.

L atacz-L ohmann, U . and C. Foster. 1997. From "niche" to "mainstream" - Strategies for marketing organic food in Germany and the U K. Brit. Food J. 99:275282.

Lohr, L. 1998. Implications of organic certification for market structureand trade. Amer. J. Agr. Econ. 80:1125-1129.

Organic Trade Association. 1998. $M$ anufacturer's market survey. 0 rg. Trade Assn., Greenfield, M ass.

Malz, A. 1998. U pdate on Argentina's organic sector. U SD A Foreign Agr. Serv., GAIN Rpt. \#AR8066, Wash., D.C.

M ichelsen, J. 1996. O rganic farmers and conventional distribution systems: the recent expansion of the organic food market in D enmark. Amer. J. Alt. Agr. 11:18-24.

M isra, S.K., C.L. H uang, and S.L. Ott. 1991. Consumer willingness to pay for pesticide-free fresh produce. W.J. Agr. Econ. 16:218-227.

M yles, G.C. 1997. The organic food market in C anada. U SD A Foreign Agr. Serv., AGR \#CA7032, Wash., D.C.

$\mathrm{N}$ atural Foods M erchandiser, 1998. N ew Hope Communications, Boulder, Colo., August $X I X, 8$.

Perng, C.M. 1998. O rganic food trend wins in T ai wan. U .S. D epartment of Agriculture, Foreign Agricultural Service, Foreign Agricultural Service O nline. 13 Feb. 1999. http:// ffas.usda.gov/ info/ agexporter/ 1998/orgtaiw.html.

Produce Studies G roup. 1998. The E uropean organic food market, final report. 
U SDA, The $\mathrm{H}$ ague, The $\mathrm{N}$ etherlands.

Regini, F. and C. Sloop. 1996. Italy: organic products. U SD A Foreign Agr. Serv., AGR \# T6051, Washington, D.C.

Reicks, M., P. Splett, and A. Fishman. 1997. Shelf labeling of organic foods: Effects on customer perceptions and sales. Retail Food Ind. Ctr., U niv. M inn., St. Paul, Working Paper 97-03.

Saunders, C., J. M anhire, H. Campbell, and J. Fairweather. 1997. O rganic farming in New Zealand: An evaluation of the current and future prospects including an assessment of research needs. $M$ in. Agr. For. Policy Tech. Paper 97/ 13, Dept. E con. M ktg., L incoln U niv., Canterbury, $\mathrm{N}$ ew Zealand.

Saunders, C. 1999. The potential for expansion of the organic industry in $\mathrm{New}$ Zealand: A contingent evaluation of consumers willingness to pay for organic produce. Commerce Div. Discussion Paper 77, Commerce D iv., Lincoln U niv., C anterbury, N ew Zealand.

Sharpless, M.R. and R. Gauthier. 1998. U SDA Foreign Agr. Serv., Foreign Agr. Serv. O nline. 13 Feb. 1999. http:// www.fas. usda.gov/ info/ agexporter/ 1998/ orgH oK oc.html.

Sparling, E., K. Wilken, and J. M cKenzie. 1992. M arketing fresh organic produce in Colorado supermarkets. C olo. D ept. Agr./ U SD A Fed. State M ktg. I mprov. Prog., Ft. Collins.

Seki, T . 1997. Study on J apanese organic food market. M arket and I nd. Serv. Branch, Agr. and Agri-Food C anada, O ttawa, O ntario.

Swanson, R.B. and C.E. L ewis. 1993. Alaskan direct-market consumers: perception of organic produce. Home Econ. Res. J. 221:38-155.
Tesco. 1998. Products-Fresh produce. Tesco website. 2 Dec. 1999.http:/ / www.tesco.co.uk/ information/ fact_file/ products_fresh.asp.

The Packer. 1998. Fresh trends. Vance Publishing, O verland Park, Kan.

Thompson, G.D. and J. Kidwell. 1998. Explaining the choice of organic produce: cosmetic defects, prices, and consumer preferences. Amer. J. Agr. E con. 80:277287

Thompson, G.D. 1998. Consumer demand for organic foods: What we know and what we need to know. Amer. J. Agr. Econ. 80:113-1118.

Thorburn II, W.G. 1998. Organic food trend sprouts in $\mathrm{H}$ ong Kong. U SD A Foreign Agr. Serv., Foreign Agr. Serv. O nline. 15 Feb. 1999. http:/ / www.fas.usda.gov/ info/ agexporter/ 1998/ orgH oKoc.html.

T regear, A., J.B.D ent, and M .J . M cG regor. 1994. The demand for organically-grown produce. Brit. Food J . 96:21-25.

U .S. E mbassy, Stockholm. 1998. Sweden: Organic products. USDA Foreign Agr. Serv., GAIN Report \#SW8009, Wash., D.C.

van der $\mathrm{H}$ arst-Collaris, T. and L.G. Scandurra. 1997. Dutch organic food market offers all-natural potential for U .S. firms. U SD A Foreign Agr. Serv., Foreign Agr. Serv. O nline. 18 Jan. 1999. http:/ / www.fas.usda.gov/ info/ agexporter/ 1997/ dutch.html.

van der $\mathrm{H}$ arst-Collaris, T. 1998. Largest supermarket in the $\mathrm{N}$ etherlands increases the number of private band organic products. U SD A Foreign Agr. Serv. Voluntary Rpt. AGR\#N L 8011, Wash., D.C.

Vastola, A. 1997. Perceived quality and certification: The case of organic fruit. In: G. Schiefer and R. H elbig (eds.). Q uality management and processimprovement for competitive advantage in agriculture and food. vol. 1. $49^{\text {th }}$ seminar of the E uropean association of agricultural economists. Bonn, Germany.

Waitrose Supermarkets. 1999. Organic products. Waitrose website. $2 \mathrm{Dec} .1999$. http: / / w w w.waitrose.co.uk/ orgprods.htm.

Wang, Q., C. H albrendt, and S. Webb. 1997. Consumer demand for organic foods in urban C hina: evidencefrom survey data. In: W. Lockeretz (ed.). Agricultural production and nutrition. Tufts U niversity School of Nutr. Sci. and Policy, Boston, M ass.

W eaver, R.D ., D .J . E vans, and A.E . L uloff. 1992. Pesticide use in tomato production: consumer concernsand willingness-to-pay. Agribus., An Intl. J. 8:131-142.

Weir, T. 1998. An unnatural alliance. Supermarket Bus. 53:13-24.

Wilson, P.N., G.D. Thompson, and R. Cook. 1997. M other nature, business strategy, and the fresh produce industry. Choices. (1st quarter):18-21,24-25.

World Bank. 1998. World development report. Oxford U niv. Press, N ew York.

Wyler, A. 1998. Swiss organic market. U SD A Foreign Agr. Serv. M ktg. D ev. R pt. AGR SZ8006, Wash., D.C.

Zenner, S. and R.v. Ziehlberg. 1998. Der markt für bio-produkt in Ö sterreich. I nsitut für Agrarökonomie der U niversität Kiel, Lerhstuhl für Agrarmarketing, O Ishausenstrasse 40, D -24118, Kiel, Germany.

Zygmont, J. 1998. Chile. Organic perspectives, U SD A, Foreign Agr. Serv., Foreign Agr. Serv. O nline, 18 Jan. 1999. http:/ / www.fas.usda.gov/ htp/ organics. 